\title{
Quasi-immune response of Penaeus japonicus to penaeid rod-shaped DNA virus (PRDV)
}

\author{
C. A. Venegas ${ }^{1, *}$, L. Nonaka ${ }^{1}$, K. Mushiake ${ }^{2}$, T. Nishizawa ${ }^{1}{ }^{1}$ K. Muroga ${ }^{1, * *}$ \\ ${ }^{1}$ Laboratory of Fish Pathology, Faculty of Applied Biological Science, Hiroshima University, \\ Higashihiroshima 739-8528, Japan \\ ${ }^{2}$ Kamiura Station of Japan Sea-Farming Association, Kamiura, Oita 879-2602, Japan
}

\begin{abstract}
A quasi-immune response was demonstrated in kuruma prawn Penaeus japonicus infected naturally or experimentally with PRDV (penaeid rod-shaped DNA virus, also called white spot syndrome virus or WSSV), the causative agent of PAV (penaeid acute viremia). In the first step of this study, natural survivors 4 mo after a PAV outbreak demonstrated $94 \%$ relative percent survival (RPS) upon experimental PRDV challenge. Mortalities after challenge were confirmed by PRDV detection to be due to PAV using a PCR method. In the second step, experimental PAV survivors were produced by intramuscular (IM) injection of PRDV into naive shrimp subsequently reared collectively in a tank (A group) or individually in chamber units (B group). Survival was 41 and $90 \%$ in the A and B groups, respectively. A subsequent IM re-challenge of these PRDV survivor groups with PRDV made $32 \mathrm{~d}$ after the first challenge revealed a protective response with high RPS of 77 and $64 \%$, respectively. These high survival rates suggested that PAV survivors (natural or experimental) were able to resist PRDV infection and that the resistance was not due to selection of naturally resistant shrimp during a PAV outbreak, but due to enhancement of an immune-like system (quasi-immune response) after exposure to PRDV. No PRDV neutralizing activity was revealed in the serum of the 4 mo natural survivors of the PRDV outbreak. However, it was found in their serum $17 \mathrm{~d}$ after they had been experimentally challenged with PRDV.
\end{abstract}

KEY WORDS: Penaeid acute viremia (PAV) · Penaeid rod-shaped DNA virus (PRDV) · White spot syndrome virus $(\mathrm{WSSV}) \cdot$ Immune response $\cdot$ Penaeus japonicus

Resale or republication not permitted without written consent of the publisher

\section{INTRODUCTION}

Since 1993, the Japanese shrimp industry has been hampered by the appearance of penaeid rod-shaped DNA virus (PRDV) which causes penaeid acute viremia (PAV) (Takahashi et al. 1998). In the beginning of the PAV epizootic, mass mortalities were observed only from farms where Penaeus japonicus seed stocks were imported from China (Nakano et al. 1994, Takahashi et al. 1994). This event was followed by a rapid spread of the disease affecting the harvesting rates of farmed kuruma prawn in all western Japan. The etio-

*Present address: Unit of Aquatic Animal Pathology, Dept. of Animal Pathology, Faculty of Veterinary Sciences, University of Chile, Santiago de Chile, Chile

${ }^{* *}$ Corresponding author. E-mail: fpath@hiroshima-u.ac.jp logical agent was described as a rod-shaped enveloped bacilliform virus, tentatively named RV-PJ (rod-shaped nuclear virus of $P$. japonicus) (Inouye et al. 1994). Later it was renamed PRDV along with the disease name, PAV (Inouye et al. 1996). The same disease, generally called white spot syndrome (WSS, Lightner 1996), has been reported in shrimp farming regions of Asia (Chou et al. 1995, Peng et al. 1995, Wongteerasupaya et al. 1995, Karunasagar et al. 1997, Park et al. 1998) and in the Americas (Nunan et al. 1998, Jory 1999), causing significant economic losses.

PAV or WSS is grossly characterized by the presence of white spots all over the shrimp cuticle and histologically by hypertrophied nuclei of the target organs embryologically derived from the ectoderm and mesoderm (Momoyama et al. 1994, Wang et al. 1999). White spot syndrome virus (WSSV) complex has a wide host 
range among penaeid shrimp (Lightner 1996) and other crustaceans (Lo et al. 1996, Maeda et al. 1998a). So far, PAV has caused mass mortalities in cultured kuruma prawn and greasyback shrimp Metapenaeus ensis in Japan (Momoyama et al. 1997). It was experimentally demonstrated that 6 species of crustaceans, the major species for seed production programs in Japan, are all susceptible to PRDV, although some (Penaeus semisulcatus and Portunus trituberculatus) have a lower susceptibility than $P$. japonicus (Momoyama et al. 1999). However, it was revealed that larval stages and younger postlarvae (PL) (younger than PL 10) of kuruma prawn were not susceptible to the virus (Venegas et al. 1999).

The first microscopic diagnostic method was introduced based on the pathognomonic changes in affected shrimp, i.e. abundant presence of the viral particles in the hemolymph (viremia) and hypertrophied nuclei of the infected cells (Momoyama et al. 1995). In 1996, PRDV-specific primers for polymerase chain reaction (PCR) detection were developed (Kimura et al. 1996, Takahashi et al. 1996). PCR, mainly with the primers developed by Kimura et al. (1996), is widely used as the routine diagnostic means in Japan. In research work, an in situ hybridization technique has also been used to detect PRDV (Momoyama et al. 1999).

Currently, the epizootiological landscape of PAV in Japan is quite different from that of the early stages. Although it has become an enzootic sanitary problem on Japanese coasts, due to countermeasures that have been practiced in shrimp farms and hatcheries the prevalence of the disease is not so high as in the first few years. Among them, the production of SPF (specific pathogen free) juveniles in hatcheries by means of selection of PRDV-negative wild broodstock (Mushiake et al. 1998, 1999, Satoh et al. 1999) and release of PRDV-negative juveniles to restock coastal waters (Yamano et al. 1998) have been effective for this amelioration. Effects of various chemical treatments on PRDV were tested (Maeda et al. 1998b, Nakano et al. 1998) and disinfection of eggs with iodine has been practiced (Satoh et al. 1999), though strict efficacy has not yet been proven in hatcheries.

A phenomenon of tolerance has been observed in Penaeus monodon in Thailand in the cases of WSSV and YHV (yellow head virus) (Flegel et al. 1997). According to Flegel (1997), the shrimp appeared to have rapidly developed a tolerance against the new virus (systemic ectodermal and mesodermal baculovirus, SEMBV: homologous to WSSV and PRDV) within a period of $1.5 \mathrm{yr}$ since it first caused heavy losses. Flegel (1997) hypothesized that this specific viral tolerance was developed within the lifetime of a single batch of shrimp, but the exact mechanism is unknown. Concerning this phenomenon, Flegel \& Pasharawipas (1998) hypothesized that tolerance to viral infections in crustaceans is the manifestation of an active system for accomodation that is based on membrane binding involving specific memory, leading to supression of viral triggered apoptosis and to persistent innocuous infections. However, data which indicate the presence of an acquired tolerance against PRDV (or WSSV) in penaeid shrimp have been scarce. A similar phenomenon was observed in a shrimp farm in Hiroshima, Japan, revealing a resistance in surviving shrimp against experimental PRDV challenge. Moreover, by artificial infection, the present authors could produce 'immune shrimp' whose resistance was confirmed by a viral re-challenge.

\section{MATERIALS AND METHODS}

This study began by monitoring the prevalence of infection in kuruma prawns following a PAV outbreak (Expt 1). The resistance of surviving shrimp (NS: natural survivors) was then tested by experimental challenge with PRDV (Expt 2). In order to artificially produce resistant individuals, kuruma shrimp were injected intramuscularly (IM) with PRDV, and survivors (ES: experimental survivors) were challenged again after $32 \mathrm{~d}$ of rearing in a tank or in individual chamber units (Expt 3). Serum samples obtained from NS shrimp and from surviving shrimp of Expt 2 (NES: surviving natural epizootic and subsequent experimental challenge) were tested for their neutralizing activity against PRDV (Expts 4 to 6).

For the challenge test, the following virus source was used in Expts 2 to 6, all of which were carried out in the Kamiura Station of Japan Sea-Farming Association (JASFA). Prior to and following the challenge, shrimp were reared at a water temperature ranging from 19 to $21^{\circ} \mathrm{C}$ and fed a commercial crumbled feed.

Virus source. A homogenate was made from naturally PRDV-infected juveniles of Penaeus japonicus, diluted 4 times in sterile phosphate-buffered saline (PBS) and then centrifuged at $1600 \times g$ for $10 \mathrm{~min}$ at $4{ }^{\circ} \mathrm{C}$. The supernatant was filtered through a $0.45 \mu \mathrm{m}$ cellulose acetate membrane, collected and stored at $-80^{\circ} \mathrm{C}$ until the infection trials were performed.

PCR analysis for PRDV. Muscle was homogenized and digested in a mixed solution containing proteinase $\mathrm{K}\left(1 \mathrm{mg} \mathrm{m}{ }^{-1}\right.$; Merck) and SDS (1\% w/v). After incubation at $37^{\circ} \mathrm{C}$ for $15 \mathrm{~min}$, the DNA extraction was done following a protocol designed in our laboratory (Nonaka et al. 1998). Briefly, the DNA was extracted twice with phenol-saturated TE $(10 \mathrm{mM}$ Tris- $\mathrm{HCl}$, 1 mM EDTA, pH 8.0) and once with chloroform/ isoamylalcohol $(24: 1)$. The solution was then treated 
with $5 \mathrm{M}$ ammonium acetate and absolute ethanol, centrifuged $(12000 \times g, 15 \mathrm{~min})$ and submitted to RNase A (20 $\mathrm{g} \mathrm{m} \mathrm{ml}^{-1}$; Nacalai tesque) digestion. Thereafter, the DNA was recovered by treatment with $20 \%$ PEG 6000 solution, washed with $70 \%$ (v/v) ethanol by centrifugation $(12000 \times g, 2 \mathrm{~min})$ and dried. The dried pellets were then resuspended in TE buffer. The detection primers used were P1-P2 (for 1st-step PCR) and P3-P4 (for 2nd-step) previously described by Kimura et al. (1996) for PRDV diagnosis. The detection was performed by 1-step amplification for 30 (without notice) or 40 cycles in a temperature control system (Astec PC800, Japan). Negative samples were submitted to a 2nd amplification (nested PCR).

For electrophoresis of the PCR products, $1.5 \%$ agarose gels in $0.5 \times \mathrm{TAE}(40 \mathrm{mM}$ Tris-acetate $\mathrm{pH}$ 8.0, $0.1 \mathrm{mM}$ EDTA) were used. After electrophoresis, the minigels were stained with ethidium bromide and visualized by ultraviolet transillumination.

Expt 1. Field monitoring for prevalence of infected shrimp. A survey of the occurrence of PAV and prevalence of PRDV was conducted from July to November 1997 (summer and autumn seasons) in a private shrimp farm located in Hiroshima Prefecture in western Japan. On each sampling date, 6 or 10 live individuals were sampled and submitted to PCR amplification for detection of PRDV following the extraction method described above.

Expt 2. PRDV challenge of NS. In November 1997 (about 4 mo after a natural outbreak), NS were challenged with the PRDV preparation with a control counterpart derived from naive shrimp obtained from a farm in Kagoshima Prefecture without history of PAV occurrence in that year. Prior to the challenge, shrimp from both groups were checked for the presence of PRDV by PCR (1-step, 40 cycles). For challenge of the NS and naive shrimp, a dose of $100 \mu$ l of $10^{-2}$ diluted PRDV preparation was injected IM, while control shrimp of the 2 types were injected with sterile PBS. For each group 20 individuals with an average body weight of $20 \mathrm{~g}$ were used (total 80). After the challenge, the shrimp were held in 5001 tanks supplied with flowing seawater and aeration. Mortalities were recorded through a period of $16 \mathrm{~d}$. Dead shrimp were submitted to PCR tests for detection of PRDV. NES shrimp were retained for further study.

Expt 3. PRDV challenge of ES. ES were used in a challenge test with PRDV. To produce ES, shrimp ranging 1.5 to $2 \mathrm{~g}$ in body weight $(\mathrm{n}=318)$, derived from PRDV-negative broodstock and raised in Kamiura Station without PAV experience, were challenged by IM injection with $10^{-8}$ dilution of the viral preparation at a dose of $10 \mu \mathrm{l}$ ind. ${ }^{-1}$. Afterwards, 213 of the challenged shrimp were collectively held in a $500 \mathrm{l}$ plastic tank (collectively reared, 'Coll' group) while the remainder were held in individual chamber units (i.e. 105 chambers filled with $600 \mathrm{ml}$ seawater each; individually reared, 'Ind' group). Another group from the same batch was injected with sterile PBS $(n=150)$ in order to provide a control group for the subsequent challenges. The PRDV-challenged shrimp were observed until peak mortality had passed (i.e., $32 \mathrm{~d}$ after injection challenge). Mortalities were confirmed as specific for PRDV by PCR, but PCR tests were not applied to the survivors before re-challenge.

In the re-challenge test, a dose of $10 \mu \mathrm{l}$ of a $10^{-4}$ dilution of the viral preparation was injected IM into each of 23 survivors from the 'Coll' and 'Ind' groups. A group of 25 of the control shrimp, previously injected with PBS, was also challenged with the same viral dilution. The shrimp of each group were held collectively in separate 301 plastic tanks supplied with flowing water and aeration. For mortality, the shrimp were observed for 16 ('Coll' group) or 17 ('Ind' group) d, and dead shrimp were tested by PCR for PRDV.

Expt 4. Challenge using PRDV mixed with NS serum. Serum from natural PAV-survivors (NS serum) was collected about 4 mo after the farm disease outbreak. From each shrimp $0.5 \mathrm{ml}$ of hemolymph was drawn without any anticoagulant but by diluting 5 times with PBS in the syringe followed by centrifugation $(1600 \times g, 5 \mathrm{~min})$ to remove hemocytes. The NS serum obtained $(0.1 \mathrm{ml})$ was mixed with $0.9 \mathrm{ml}$ of the PRDV preparation (diluted $10^{-2}$ ) and kept for $3 \mathrm{~h}$ at $20^{\circ} \mathrm{C}$. The serum-virus mixture was then injected IM at a dose of $100 \mu \mathrm{l}$ per $20 \mathrm{~g}$ naive shrimp. Naive positive controls were injected with PRDV mixed with normal serum or with PBS and naive negative controls with PBS alone. Afterwards, the shrimp were held in 5001 tanks with a flow through water system and monitored for survival for $24 \mathrm{~d}$. This experiment was run together with Expt 5, so that the same controls served for both.

Expt 5. Challenge using PRDV mixed with NES serum. Serum from survivors of Expt 2 (NES) was collected and treated in the same manner as in Expt 4 and injected similarly into $20 \mathrm{~g}$ naive shrimp using the same positive and negative controls as in Expt 4. Afterwards, the shrimp were held in $500 \mathrm{l}$ tanks with a flow through water system and monitored for survival for $24 \mathrm{~d}$.

Expt 6. PRDV neutralization test with NES serum. A neutralizing experiment with NES serum was carried out using younger naive shrimp (1.5 g). In this experiment, in order to avoid effects of NES serum in injected experimental specimens, the virus-serum mixture was ultracentrifugated $\left(30000 \times g, 45 \mathrm{~min}\right.$ at $\left.4^{\circ} \mathrm{C}\right)$ after being kept at $20^{\circ} \mathrm{C}$ for $3 \mathrm{~h}$ and PRDV was resuspended in the original volume of PBS prior to IM injection $\left(10 \mu \mathrm{l}\right.$ shrimp $\left.^{-1}\right)$. There were 2 positive control groups, 1 injected IM with uncentrifuged PRDV prepa- 
ration and 1 with ultracentrifuged and reconstituted PRDV preparation. The negative control group was injected with PBS.

Statistical methods. The mortalities of the tested and control groups were statistically compared using chisquare test $\left(\chi^{2}\right)$ at a significance level of $5 \%$ and the relative percent survival [RPS \%= (1-'vaccinated' group mortality/control group mortality) $\times 100$ ] was also calculated (Amend 1981).

\section{RESULTS}

\section{Expt 1. Prevalence of PRDV-infected shrimp in the sampled farm (Table 1)}

The shrimp sampled on July 3 revealed no presence of PRDV DNA and no significant mortality was recorded in the farm. In late July (middle of summer), a PAV outbreak occurred in the farm resulting in high mortality (estimated $60 \%$ ) with PCR-positive results in all sampled individuals. However, after the peak of the epizootic, few of the surviving shrimp died from PAV in the late summer and autumn, despite the persistence of PRDV in the survivors as indicated by PCR tests.

\section{Expt 2. Challenge of NS shrimp (Fig. 1)}

Prior to challenge, 1-step PCR positive rates of the NS and PAV-inexperienced control shrimp were 43 and $0 \%$, respectively. A significant difference in survival rate after the challenge test was observed

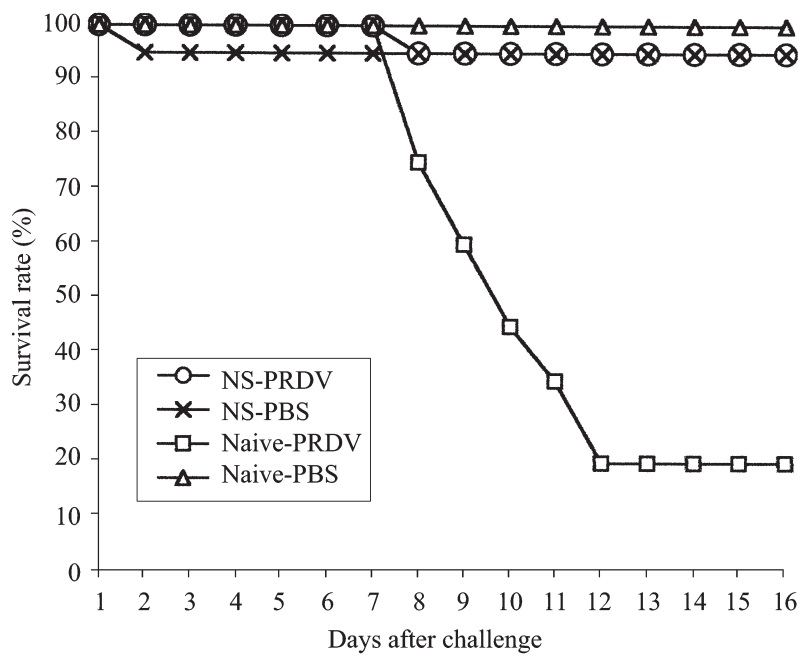

Fig. 1. Results of Expt 2. Survival rates of natural PAVsurvivors (NS) of Penaeus japonicus and naive shrimp challenged by intramuscular injection with PRDV. Controls were injected with PBS
Table 1. Results of Expt 1. Changes in PRDV detection rate by PCR in Penaeus japonicus survivors from an outbreak of PAV in a shrimp farm

\begin{tabular}{|llc|}
\hline $\begin{array}{l}\text { Sampling } \\
\text { date in } \\
1997\end{array}$ & $\begin{array}{c}\text { Sample source } \\
\text { (all from Pond 2) }\end{array}$ & $\begin{array}{c}\text { PRDV detection rate by } \\
\text { PCR (40 cycles) } \\
\text { No. positive/examined }\end{array}$ \\
\hline Jul 3 & Healthy shrimp & $0 / 6$ \\
Jul 23 & Apparently healthy & $6 / 6$ \\
& and diseased & \\
Aug 12 & Survivors (healthy) & $9 / 10$ \\
Sep 10 & Survivors (healthy) & $8 / 10$ \\
Oct 11 & Survivors (healthy) & $5 / 10$ \\
Nov 14 & Survivors (healthy) & $2 / 10$ \\
\hline
\end{tabular}

between the NS and control shrimp (95 and 20\%, respectively) with an RPS of $94 \%$ for the NS group. Positive PCR reactions were detected from all dead shrimp.

\section{Expt 3. PRDV challenge of ES (Fig. 2)}

Cumulative mortalities during $32 \mathrm{~d}$ following the preparatory laboratory challenge were 59,10 , and $3 \%$, in 'Coll' and 'Ind' groups and the PBS injected control group, respectively. The mortalities were significantly different $(p<0.05)$ between the 'Coll' and 'Ind' groups. When the PAV survivors (ES-'Coll' and ES-'Ind') and the PBS-injected control shrimp were subsequently challenged with PRDV, both ES groups gave significantly different survival rates $(p<0.05)$ from the control group (see Fig. 2). Calculated RPS were 77 and

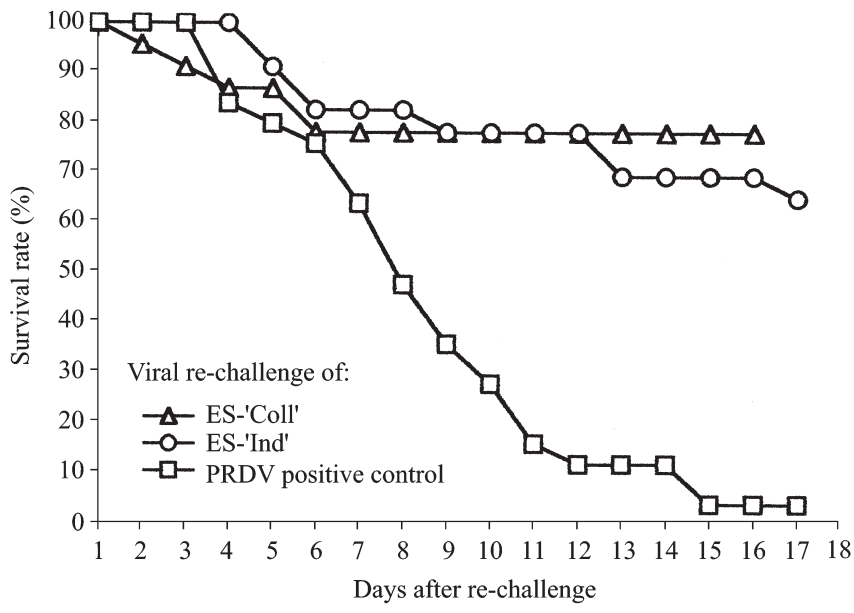

Fig. 2. Results of Expt 3. Survival rates of experimental PAVsurvivors (ES) of Penaeus japonicus, either reared collectively (ES-'Coll') or individually (ES-'Ind'), re-challenged with PRDV $32 \mathrm{~d}$ after first exposure to the virus 
$64 \%$ for the ES-'Coll' and ES-'Ind' groups, respectively. Most of the dead shrimp were confirmed to be PRDV positive by PCR. However, PRDV DNA could not be detected from decaying carcasses. The PCR detection rates in survivors after the re-challenge were $27 \%(5 / 18)$ and $0 \%(0 / 18)$ in the ES- 'Coll' and ES-'Ind' groups, respectively.

\section{Expt 4. Challenge using PRDV mixed with NS serum (Fig. 3)}

The group challenged with the mixture of virus and NS serum had a survival rate of $15 \%$ when compared to the negative control group of $100 \%$ and the 2 positive control groups, one injected with non-treated virus $(30 \%)$ and the other with a mixture of virus and normal serum (35\%). Thus, the NS serum showed no protective effect.

\section{Expt 5. Challenge using PRDV mixed with NES serum (Fig. 3)}

A significantly higher survival rate of $85 \%$ was revealed in the group challenged with a mixture of PRDV and NES serum when compared to the 2 foregoing positive control groups. An interesting observation was a high detection rate for PRDV by 1-step PCR $(60 \%)$ among the survivors.

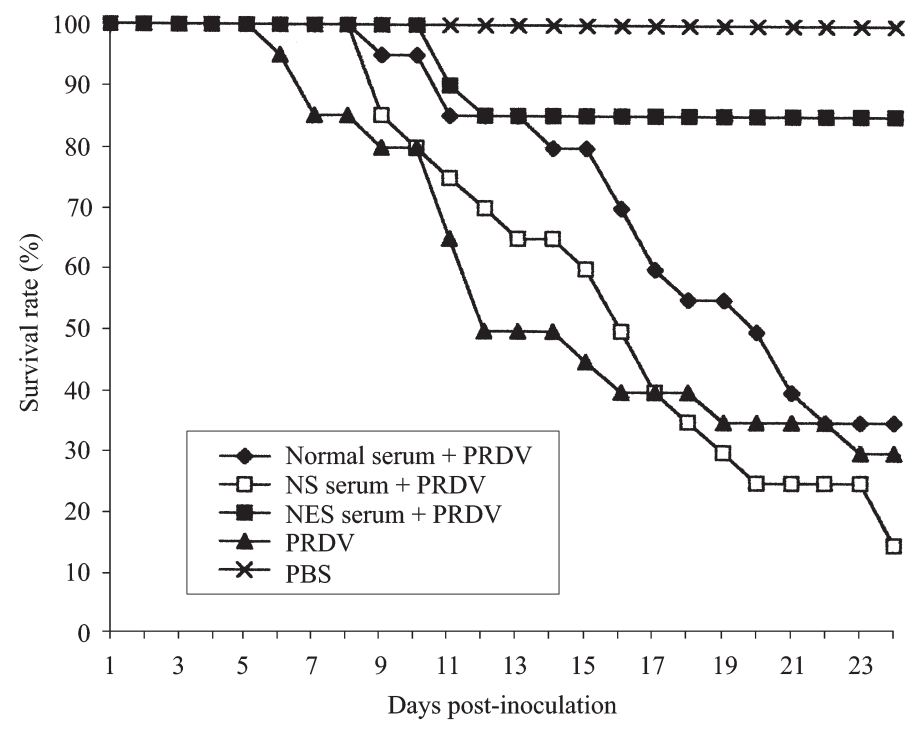

Fig. 3. Results of Expts 4 and 5. Survival rates of naive Penaeus japonicus (20 g average body weight) injected IM with the mixture of PRDV and NS serum or NES serum. Controls were injected with PRDV alone (positive control), PBS (negative control) or a mixture of the virus and normal shrimp serum
Table 2. Result of Expt 6. A neutralization test of centrifuged and non-centrifuged PRDV with NES serum. Survival rates and RPS (relative percent survival) are given for naive Penaeus japonicus (1.5 g average body weight) injected IM with the virus with or without ultracentrifugation. Controls were injected with PRDV alone (ultracentrifuged or not) or PBS

\begin{tabular}{|lccc|}
\hline Group (injected with) & $\mathrm{n}$ & Survival (\%) & RPS (\%) \\
\hline $\begin{array}{l}\text { PRDV centrifuged } \\
\text { with NES serum }\end{array}$ & 30 & 77 & 71 \\
$\begin{array}{l}\text { PRDV centrifuged with } \\
\text { PBS (positive control) } \\
\text { PRDV non-centrifuged } \\
\text { (positive control) }\end{array}$ & 28 & 21 & \\
PBS (negative control) & 30 & 13 & \\
\hline
\end{tabular}

\section{Expt 6. PRDV neutralization test with NES serum} (Table 2)

A similar high survival rate $(77 \%)$ was attained in the group of younger shrimp injected with virus solution prepared by mixing with NES serum followed by ultracentrifugation. The RPS was $71 \%$ (Table 2). As with Expt 5, there was a high detection rate for PRDV among the survivors (45\%).

\section{DISCUSSION}

The protective system in invertebrates has often been called primitive in comparison with that of vertebrates. However, this group of shrimp must have their own effective protective 'immune system'. This efficient system does not rely on an adaptive immune response based on immunoglobulins which characterize a 'true immune response'. Concerning immune defense, crustaceans are able to recognize self from non-self (Sloan et al. 1975) by means of efficient and rapid defense processes involving cellular responses (e.g. clotting, phagocytosis and encapsulation) (Söderhäll \& Cerenius 1992) and humoral responses (agglutinins, lectins, killing factors, neutralizing factors, etc.) (Smith \& Chisholm 1992). These responses have now become important due to the new emerging viral diseases facing the shrimp culture industry, e.g. YHD (Flegel 1997), Taura syndrome (TS; Lightner \& Redman 1998), and WSS/PAV. Currently, the epizootiology of YHD and WSS shows a decrease in mortalities owing to a kind of tolerance that may be triggered in the shrimp (Flegel \& Pasharawipas 1998). It has also been reported for TSV that survivors of naturally occurring epizootics were resistant to subsequent infection if challenged by TSV (Lightner \& Redman 1998). 
However, few data demonstrating the presence of tolerance or resistance have been presented. Our investigation represents the first attempt to determine whether this kind of immune response could be triggered in shrimp by infection with PRDV in natural and experimental situations.

In our first experiment, it was observed that PAV recurrence scarcely occurred in the studied shrimp farm, despite the high prevalence of PRDV infection in surviving shrimp (NS) detected by PCR tests. Upon experimental challenge with PRDV, these NS shrimp showed high survival (95\%) when compared to the control shrimp (20\%). Since the control shrimp in this experiment comprised Penaeus japonicus obtained from a different location than the NS shrimp (because naive shrimp could not be obtained from the same or neighbouring farms), it might be argued that the differences in survival in the experiment were due to differences in natural resistance to PRDV as a result of selection during the PAV outbreak. We attempted to test this argument in Expt 3, where the ES shrimp and control shrimp were derived from the same batch of test animals in order to avoid genetic variation. We also reared the ES shrimp collectively and individually to test effects of crowding stress. Although the results of Expt 3 confirmed that PAV survivors were protected upon re-challenge with PRDV, there were significant differences $(p<0.05)$ in mortalities for shrimp reared collectively (59\%) and individually (10\%) during the preparatory challenge phase for the experiment. Thus, the possibility for some selection of innately resistant individuals remains open, since there was higher cumulative mortality in the 'Coll' group than in the 'Ind' group. In spite of this, the fact that RPS for the collectively and individually reared ES shrimp were both very high (77 and $64 \%$ ) and not greatly different indicates that the PRDV protection resulted largely from exposure to the virus and not to innate resistance. Thus, the protection appeared to be acquired after exposure to the virus and might be called a 'quasiimmune response'.

It is not clear why there was a significant difference after PRDV challenge in the mortality of 'Coll' shrimp and 'Ind' shrimp. It could have been brought about by differences in stress or by cannibalism in one group but not the other. However, detailed studies should be carried out to elucidate the effect of rearing conditions on the outcome of infections.

Although we did not examine other factors, including cellular ones, our experiments with serum-virus mixtures (i.e., the neutralization tests) suggest that there may be a PRDV neutralizing factor (or non-specific binding factor) in the hemolymph of NES for up to 17 d after challenge with PRDV. However, such apparent neutralizing activity was not detected from ES 4 mo after a PAV outbreak, even though they gave high survival (95\%) upon PRDV challenge. This means that the 'neutralizing factor' is not indispensable for the acquired protection shown in the present study. Possibly, this 'neutralizing factor' does not continue to exist long after exposure to virus but may be enhanced by secondary exposure (laboratory challenge). As mentioned in a study on the convalescent stage of experimental TS in Penaeus vannamei (Hasson et al. 1999), a cellmediated defense mechanism might also be involved in the present 'quasi-immune response'.

As mentioned above, Flegel \& Pasharawipas (1998) presented an interesting hypothesis on acquired tolerance of shrimp to viral pathogens. So far we could confirm the basic phenomenon of acquired resistance or a 'quasi-immune response' in Penaeus japonicus to PRDV, but we have no further materials to make available arguments to support or criticize their hypothesis. The positive PCR results were sometimes observed in resistant survivors at the end of re-challenge tests, but we did not examine whether the virus positively replicated in them or not. In our study, important tasks remain to elucidate the duration and specificity of the 'quasi-immune response' and the nature of the factors, humoral and cellular, involved in the phenomenon.

\section{LITERATURE CITED}

Amend DF (1981) Potency testing of fish vaccines. In: Anderson DP, Hennessen W (eds) Developments in biological standarization, Vol 49. Fish biologics: serodiagnostics and vaccines. S. Karger, Basel, p 447-454

Chou HY, Huang CY, Wang CH, Chiang HC, Lo CF (1995) Pathogenicity of a baculovirus infection causing white spot syndrome in cultured penaeid shrimp in Taiwan. Dis Aquat Org 23:165-173

Flegel TW (1997) Major viral diseases of the black tiger prawn (Penaeus monodon) in Thailand. In: New approaches to viral diseases of aquatic animals. National Research Institute of Aquaculture, Nansei, Mie, Japan, p 167-189

Flegel TW, Pasharawipas T (1998) Active viral accomodation: a new concept for crustacean response to viral pathogens. In: Flegel TW (ed) Advances in shrimp biotechnology. National Center for Genetic Engineering and Biotechnology, Bangkok, p 245-250

Flegel TW, Boonyaratpalin S, Withyachumnarnkul B (1997) Current status of research on yellow-head virus and white-spot virus in Thailand. In: Flegel TW, MacRae I (eds) Diseases in Asian aquaculture III. Fish Health Section, Asian Fisheries Society, Manila, p 285-296

Hasson KW, Lightner DV, Mohney LL, Redman RM, White BM (1999) Role of lymphoid organ spheroids in chronic Taura syndrome virus (TSV) infections in Penaeus vannamei. Dis Aquat Org 38:93-105

Inouye $\mathrm{K}$, Miwa $\mathrm{S}$, Oseko N, Nakano H, Kimura T, Momoyama K, Hiraoka M (1994) Mass mortalities of cultured kuruma shrimp Penaeus japonicus in Japan in 1993: electron microscopic evidence of the causative virus. Fish Pathol 29:149-158 
Inouye K, Yamano K, Ikeda N, Kimura T, Nakano H, Momoyama K, Kobayashi J, Miyajima S (1996) The penaeid rodshaped DNA virus (PRDV), which causes penaid acute viremia (PAV). Fish Pathol 31:39-45

Jory D (ed) (1999) Shrimp white spot disease in Latin America-an update. Global Aquacult Advocate 2(3). http:// www.gaalliance.org/june99.html

Karunasagar I, Otta SK, Karunasagar I (1997) Histopathologi$\mathrm{cal}$ and bacteriological study of white spot syndrome of Penaeus monodon along the west coast of India. Aquaculture 153:9-13

Kimura T, Yamano K, Nakano H, Momoyama K, Hiraoka M, Inouye K (1996) Detection of penaeid rod-shaped DNA virus (PRDV) by PCR. Fish Pathol 31:93-98

Lightner DV (1996) White spot syndrome baculovirus complex (WSBV). In: Lightner DV (ed) A handbook of pathology and diagnostic procedures for diseases of penaeid shrimp Sect 3, Viruses/WSBV. World Aquaculture Society, Baton Rouge, p 1-8

Lightner DV, Redman RM (1998) Strategies for the control of viral diseases of shrimp in the Americas. Fish Pathol 33: $165-180$

Lo CF, Ho CH, Peng SE, Chen CH, Hsu HC, Chiu YL, Chang CF, Liu KF, Su MS, Wang CH, Kou GH (1996) White spot syndrome baculovirus (WSBV) detected in cultured and captured shrimp, crabs and other arthropods. Dis Aquat Org 27:215-225

Maeda M, Itami T, Furumoto A, Hennig O, Imamura T, Kondo M, Hirono I, Aoki T, Takahashi Y (1998a) Detection of penaeid rod-shaped DNA virus (PRDV) in wild-caught shrimp and other crustaceans. Fish Pathol 33:373-380

Maeda M, Kasornchandra J, Itami T, Suzuki N, Hennig O, Kondo M, Albaladejo JD, Takahashi Y (1998b) Effect of various treatment on white spot syndrome virus (WSSV) from Penaeus japonicus (Japan) and P. monodon (Thailand). Fish Pathol 33:381-387

Momoyama K, Hiraoka M, Nakano H, Koube H, Inouye K, Oseko N (1994) Mass mortalities of cutured kuruma shrimp, Penaeus japonicus, in Japan in 1993: histopathological study. Fish Pathol 29:141-148

Momoyama K, Hiraoka M, Inouye K, Kimura T, Nakano H (1995) Diagnostic techniques of rod-shaped nuclear virus infection in the kuruma shrimp, Penaeus japonicus. Fish Pathol 30:263-269

Momoyama K, Hiraoka M, Inouye K, Kimura T, Nakano H, Yasui M (1997) Mass mortalities in the production of juvenile greasyback shrimp, Metapenaeus ensis, caused by penaeid acute viremia (PAV). Fish Pathol 32:51-58

Momoyama K, Hiraoka M, Venegas CA (1999) Pathogenicity of penaeid rod-shaped DNA virus (PRDV) to juveniles of six crustacean species. Fish Pathol 34:183-188

Mushiake K, Arimoto M, Satoh J, Mori K (1998) Detection of PRDV from wild adult kuruma prawn. Fish Pathol 33: 503-510

Mushiake K, Shimizu K, Satoh J, Mori K, Arimoto M, Ohsumi S, Imaizumi K (1999) Control of penaeid acute viremia (PAV) in Penaeus japonicus: selection of eggs based on the PCR detection of the causative virus (PRDV) from receptaculum seminis of spawned broodstock. Fish Pathol 34:203-207

Nakano H, Koube H, Umezawa S, Momoyama K, Hiraoka M, Inouye K, Oseko N (1994) Mass mortalities of cultured kuruma shrimp Penaeus japonicus in Japan in 1993: epizootiological survey and infection trials. Fish Pathol 29: 135-139

Editorial responsibility: Timothy Flegel,

Bangkok, Thailand
Nakano H, Hiraoka M, Sameshima M, Kimura T, Momoyama K (1998) Inactivation of penaeid rod-shaped DNA virus (PRDV), the causative agent of penaeid acute viremia (PAV), by some chemical and physical treatments. Fish Pathol 33:65-71

Nonaka L, Venegas CA, Nishizawa T, Muroga K (1998) A method for nucleic acid extraction from kuruma prawn for PCR detection of PRDV (penaeid rod-shaped DNA virus). Fish Pathol 33:115-122

Nunan LM, Poulos BT, Lightner DV (1998) The detection of white spot syndrome virus (WSSV) and yellow head virus (YHV) in imported commodity shrimp. Aquaculture 160: 19-30

Park JH, Lee YS, Lee Y(1998) An infectious viral disease of penaeid shrimp newly found in Korea. Dis Aquat Org 34: $71-75$

Peng B, Ren J, Shen J, Zhou G, Gu H, Shen Y, Zheng G, Gong $Z$ (1995) The study on baculovirus-caused disease of prawns (Penaeus chinensis Osbeck) in Shanghai suburb. Chin J Virol 11:151-157

Satoh J, Mushiake K, Mori K, Arimoto M, Imaizumi K, Nishizawa T, Muroga K (1999) Occurrence of PAV (penaeid acute viremia) in seed production of kuruma prawn. Fish Pathol 34:33-38

Sloan B, Yokum C, Clem LW (1975) Recognition of self from non-self in crustaceans. Nature 258:521

Smith VJ, Chisholm JRS (1992) Non-cellular immunity in crustaceans. Fish Shellfish Immunol 2:1-3

Söderhäll K, Cerenius L (1992) Crustacean immunity. Annu Rev Fish Dis 2:3-23

Takahashi Y, Itami T, Kondo M, Maeda M, Fujii R, Tomonaga S, Supamattaya K, Boonyaratpalin S (1994) Electron microscopic evidence of bacilliform virus infection in kuruma shrimp (Penaeus japonicus). Fish Pathol 29: 121-125

Takahashi Y, Itami T, Maeda M, Suzuki N, Kasornchandra J, Supamattaya K, Khongpradit R, Boonyaratpalin S, Kondo M, Kawai K, Kusuda R, Hirono I, Aoki T (1996) Polymerase chain reaction (PCR) amplification of bacilliform virus (RV-PJ) DNA in Penaeus japonicus Bate and systemic ectodermal and mesodermal baculovirus (SEMBV) DNA in Penaeus monodon Fabricius. J Fish Dis 19:399-403

Takahashi Y, Itami T, Maeda M, Kondo M (1998) Bacterial and viral diseases of kuruma shrimp (Penaeus japonicus) in Japan. Fish Pathol 33:357-364

Venegas CA, Nonaka L, Mushiake K, Shimizu K, Nishizawa T, Muroga K (1999) Pathogenicity of penaeid rod-shaped DNA virus (PRDV) to kuruma prawn in different developmental stages. Fish Pathol 34:19-23

Wang YG, Hassan MD, Shariff M, Zamri SM, Chen X (1999) Histopathology and cytopathology of white spot syndrome virus (WSSV) in cultured Penaeus monodon from peninsular Malaysia with emphasis on pathogenesis and the mechanism of white spot formation. Dis Aquat Org 39: $1-11$

Wongteerasupaya C, Vickers JE, Sriurairatana S, Nash GL, Akarajamorn A, Boonsaeng V, Panyim S, Tassanakajon A, Withyachumnarnkul B, Flegel TW (1995) A non-occluded, systemic baculovirus that occurs in cells of ectodermal and mesodermal origin and causes mass mortality in the black tiger prawn Penaeus monodon. Dis Aquat Org 21:69-77

Yamano K, Kimura T, Inouye K (1998) PCR diagnosis of penaeid acute viremia (PAV) In: New approaches to viral diseases of aquatic animals. National Research Institute of Aquaculture, Nansei, Mie, Japan, p 237-241

Submitted: March 8, 2000; Accepted: May 29, 2000

Proofs received from author(s): August 1, 2000 